STUDIA ROSSICA POSNANIENSIA, vol. XLI: 2016, pp. 71-82. ISSN 0081-6884.

Adam Mickiewicz University Press, Poznań

\title{
PRZESZŁOŚĆ JAKO NAUCZYCIELKA I ŹRÓDŁO NADZIEI. WPROWADZENIE DO HISTORIOZOFII ANDRIEJA SACHAROWA
}

\author{
THE PAST AS A TUTOR AND A SOURCE OF HOPE. \\ AN INTRODUCTION TO THE HISTORIOSOPHY OF ANDREI SAKHAROV
}

\author{
BARTOSZ GOŁĄBEK
}

\begin{abstract}
The aim of this paper is to discuss the idea of the past based on Andrei Sakharov's essay titled Progress, Coexistence and Intellectual Freedom edited in 1968. Looking through the Stalinist era in the USSR, Sakharov concludes that without dealing with the Stalinist past, there is no hope of achieving peace, progress and stability in international affairs between the two main Cold War adversaries: USSR and USA.
\end{abstract}

Bartosz Gołąbek, Uniwersytet Jagielloński w Krakowie, Kraków - Polska, bartosz.golabek@uj.edu.pl

Fizyk-teoretyk, działacz społeczny, deputowany czasu pieriestrojki i wreszcie autorytet i wielki humanista, Andriej Dmitrjewicz Sacharow, to przykład osobowości, której intelektualna przemiana i forma osobistej, społecznie motywowanej walki ze stalinowskim reżimem zadziwiają i imponują do dziś. Andriej Sacharow zasłynął w dziejach ZSRR (ale i świata) jako jeden $\mathrm{z}$ największych umysłów i filarów tajnego atomowego programu w ZSRR. To pierwsze oblicze uczonego. Inna i zapewne ciekawsza strona jego publicznej działalności to aktywność w obronie praw człowieka. Mimo wielu osobistych wątpliwości i strachu, w drugiej połowie lat 60. XX wieku uczony dojrzał do otwartej, publicznej refleksji na temat broni masowego rażenia i krytyki śmiercionośnego i społecznie szkodliwego systemu, który przez wiele lat osobiście współtworzył. Upublicznienie trosk, które trapiły go od pewnego czasu, nastąpiło relatywnie późno, ale aktywność na polu walki o wolności obywatelskie w ZSRR i jego intelektualny dorobek w tym zakresie są równie imponujące, jak dokonania $w$ dziedzinie fizyki. To właśnie ten moralny i etycznie motywowany gest wybitnego, choć skromnego fizyka zdefiniował $w$ dużej mierze formację dysydencką $w$ ZSRR drugiej połowy lat 60. i późniejszych, stając się dla niej, a także dla świata, znakomitym intelektualnym autorytetem i moralnym drogowskazem ${ }^{1}$.

${ }^{1}$ Norweski Komitet Noblowski przyznał Andriejowi Sacharowowi Pokojową Nagrodę Nobla w 1975 roku. W 1988 roku Parlament Europejski ustanowił nagrodę imienia 
Spośród wielowątkowego dorobku intelektualnego tego wybitnego obrońcy praw człowieka, zawartego w wystąpieniach, listach, tekstach publicystycznych i wspomnieniowych, wątki przeszłości i historii pojawiają się jako tło dla jego intelektualnej i moralnej postawy. Trzeba podkreślić, że noblista właściwie nie planował zebrania swoich myśli i intuicji w zwartej formie pisemnej. Wszystko to, co ukazało się spod jego pióra w latach 70. i 80. XX wieku, jest właściwie zasługą intuicji jego żony Jeleny Bonner, która uznała, że sprawy, którymi się zajmował, i związane z nimi przemyślenia wymagają takiego właśnie sformalizowanego ujęcia $w$ formie tekstu ${ }^{2}$. Sam Sacharow uważał, że o ile faktycznie kwestie te mają ważkie znaczenie, to np. zdolność do literackiego ich ukształtowania nie była jego mocną stroną, o czym wprost głosił na kartach swych wspomnień ${ }^{3}$. Wydaje się, iż należy zgodzić się z myślicielem, że z filologicznego punktu widzenia ta strona jego twórczości nie jest najsilniejsza, ale klarowność przekazu i uporządkowanie tekstu, jak na praktyczny umysł przystało, zasługują na wyróżnienie.

Podejmując wątek historiozofii w tekstach Sacharowa, należy sformułować pewne zastrzeżenia, które wynikają ze specyfiki tej twórczości i jej chronologicznych uwarunkowań. Należy bowiem jasno stwierdzić, iż znaczna część jego refleksji i intuicji nabrała kształtu dopiero w latach 70. XX wie$\mathrm{ku}$, choć, jak wiadomo, przemyślenia te były mu właściwe już w latach 50 . XX stulecia, o czym mamy okazję dowiedzieć się z jego wspomnień. Biorąc pod uwagę powyższe, zasadnym jest przyjęcie dwóch dróg dotarcia do wiedzy odnośnie sposobu widzenia historii i świata przez Sacharowa. Po pierwsze źródłem tym są listy i petycje do władz państwowych, które trafiały na biurko uczonego, a przygotowywane były przez różnorakie grupy inicjatywne. Sacharow chętnie brał udział w takich kampaniach jako autorytet, dzięki czemu pośrednio możemy ocenić, jaką ideologiczną postawę wówczas reprezentował. Takie pisemne deklaracje $\mathrm{w}$ postaci petycji powstawały jeszcze przed ogłoszeniem drukiem wspomnień i dzienników Andrieja Sacharowa, które nie pozostawiają już żadnych wątpliwości odnośnie ideologicznego stanowiska ich autora. Przykładem takiego właśnie dokumentu jest jeden z pierwszych zaangażowanych politycznie i podpi-

Andrieja Sacharowa, której laureaci stanowią przykład niezłomnej walki o prawa człowieka na całym świecie. Pierwszym laureatem nagrody był Anatolij Marczenko, przyjaciel Andrieja Sacharowa, który został nią uhonorowany pośmiertnie za walkę o uwolnienie radzieckich więźniów sumienia.

2 Patrz: Wstęp do Wspomnień Andrieja Sacharowa - „Летом 1978 года по настоянию Люси, при некотором сопротивлении с моей стороны, ею преодоленном, я начал писать первые наброски воспоминаний". А. С а х а р о в, Воспоминания, т. 1, Москва 2006, s. 9.

3 Ibidem, s. 617. 
sanych przez Sacharowa listów do władz ZSRR. Jest to pismo radzieckich uczonych i intelektualistów, tzw. list dwudziestu pięciu, skierowany 14 lutego przed XXIII zjazdem KPZR w 1966 roku do Leonida Breżniewa. Jego sygnatariusze oponowali przeciwko rehabilitacji Stalina, do której, zgodnie z ich informacjami, miało dojść na zjeździe. Autorzy listu twierdzili, że deklaracje prasowe czy wystąpienia wielu działaczy politycznych poprzedzające XXIII zjazd KPZR wskazywały wyraźnie na próbę odwrócenia wektora odwilży, przynajmniej w zakresie oczyszczenia dobrego imienia Józefa Stalina. List, którego asygnatariuszem był Andriej Sacharow, prezentował jednoznacznie antystalinowskie stanowisko:

Мы считаем, что любая попытка обелить Сталина, таит в себе опасность серьезных расхождений внутри советского общества. На Сталине лежит ответственность не только за гибель бесчисленных невинных людей, за нашу неподготовленность к войне, за отход от ленинских норм в партийной и государственной жизни. Своими преступлениями и неправыми делами он так извратил идею коммунизма, что народ это никогда не простит. Наш народ не поймет и не примет отхода - хотя бы и частичного - от решений о культе личности. Вычеркнуть эти решения из его сознания и памяти не может никто ${ }^{4}$.

To jeden pierwszych dokumentów, w którym Sacharow, do tej pory znany w środowisku partyjnym głównie jako wybitny fizyk teoretyk, pracujący dla państwa na rzecz stworzenia najbardziej śmiercionośnej broni, jaką znała ludzkość, mógł zająć stanowisko poprzez złożenie swojego podpisu, a co za tym idzie i autorytetu. W swoich wspomnieniach Sacharow jednoznacznie odnotował, że podpisał ten list jako jeden z pierwszych, ale po latach dostrzegł w nim pewne braki w argumentacji, które sprawiły, że tekst nie był do końca zgodny z jego przekonaniami:

Сейчас, перечитывая текст, я нахожу многое в нем „политиканским", не соответствующим моей позиции (я говорю не об оценке преступлений Сталина - тут письмо было и с моей теперешней точки зрения правильным, быть может несколько мягким, - а о всей системе аргументации). Но это сейчас. А тогда участие в подписании этого письма, обсуждения с Генри и другими означали очень важный шаг в развитии и углублении моей общественной позиции 5 .

Są to stwierdzenia formułowane ex post i pochodzą ze wspomnień, które Sacharow zaczął spisywać pod namową żony Jeleny Bonner latem 1978 ro-

4 Письмо 25-ти деятелей советской науки, литературы и искусства Л.И. Брежневу против реабилитации И.В. Сталина, [w:] Электронная библиотека и архив Социальная история отечественной науки; http://www.ihst.ru/projects/sohist/. Dokument zachowany w archiwum autora.

${ }^{5}$ А. С а х а р о в, Воспоминания..., ор. cit., s. 582. 
$\mathrm{ku}^{6}$. Tam właśnie, dziesięć lat po liście 25-ciu, w wielu miejscach przejawia się jego antystalinowskie, ale ostatecznie nie antyradzieckie stanowisko:

Очень скоро я изгнал из этого мира Сталина (возможно, я впустил его туда совсем ненадолго и не полностью, больше для красного словца, в те несколько эмоционально искаженные дни после его смерти). Но оставались государство, страна, коммунистические идеалы. Мне потребовались годы, чтобы понять и почувствовать, как много в этих понятиях подмены, спекуляции, обмана, несоответствия реальности ${ }^{7}$.

Te sformułowania z rozdziału Wspomnień, poświęconego śmierci Józefa Stalina, wyrażają jednak pewną nadzieję na korektę polityki sowieckiego państwa. Odrzucenie stalinizmu z jednej strony, ale pozostanie przy komunistycznych ideałach $\mathrm{z}$ drugiej to nadzieja Sacharowa. W tym fragmencie swoich wspomnień uczony poszukuje po latach pewnego oczyszczenia i usprawiedliwienia, albowiem kilka fraz wcześniej jednoznacznie odnotował swój aktywny udział we wzmacnianiu militarnego potencjału powojennego ZSRR, a co za tym idzie także i Stalina. Ta autorefleksja wzbogaca naszą wiedzę o ludzkich rozterkach pryncypialnego obrońcy praw człowieka, jakim stopniowo stawał się Andriej Sacharow. Idealizacja ZSRR nie jest $\mathrm{w}$ perspektywie wspomnień Sacharowa możliwa, a tym bardziej tożsama z idealizacją osoby i postępków Józefa Stalina. Te kwestie wiary w wodza ZSRR wybitny fizyk pozostawia w przeszłości swej skomplikowanej biografii.

To swoiste wyznanie jest także właściwym początkiem krytycznej, publicznej drogi Sacharowa-dysydenta. Jego działania, inspirowane z zewnątrz, jak choćby list, o którym mowa wyżej, a także inne motywacje otworzyły drogę do jego dalszych, coraz odważniejszych ideologicznych i politycznych gestów, w których wyrażał osobiste rozumienie rosyjskiej i światowej historii. Z jego wspomnień można wyczytać wiele z postawy autora, a zwłaszcza kontekst jego intelektualnej przemiany, czy też dojrzewania, do przejścia na stronę krytyków stalinowsko-breżniewowskiego reżimu. Historia pojawia się na kartach wspomnień jako tło do biografii, zwłaszcza te jej elementy, które dotyczą młodych lat uczonego, jeszcze przed Wielką Wojną Ojczyźnianą i bezpośrednio po niej8. Kolejne wątki biografii to stopniowe utwierdzanie się fizyka, nie bez powodu, w byciu współodpowiedzialnym za bieg historii, zwłaszcza od momentu, kiedy

${ }^{6}$ Część z nich została utracona przy niejawnym przeszukaniu w listopadzie 1978 roku, część skradziona przez KGB w 1981 roku. W latach 1981-1982 Sacharow podjął się odtworzenia utraconych zapisków.

7 A. С а х а р о в, Воспоминания..., ор. cit., s. 363.

${ }^{8}$ Nagromadzenie wątków i refleksji historycznych we Wspomnieniach jest tak obfite i różnorodne, iż w ocenie autora niniejszego tekstu wymaga ujęcia w odrębnej analizie. 
zaangażowany w konstrukcję i testy bomby wodorowej na potrzeby ZSRR Sacharow zaczyna dostrzegać swoją osobistą rolę i miejsce w potencjalnie tragicznym rozwoju wypadków. Na te przemyślenia nakłada się nieodległa przeszłość ZSRR, która podlega krytycznemu osądowi ze strony jądrowego fizyka, obserwatora politycznej ewolucji powojennego stalinizmu.

Pora na dojrzałą refleksję przychodzi zgodnie $\mathrm{z}$ tą chronologią dopiero wówczas, kiedy stymulowany różnymi bodźcami zewnętrznymi i wewnętrznymi rozważa nie tyle istotę swych badań, co daleko idące konsekwencje wprowadzenia ich rezultatów w życie. Kolejne próbne eksplozje, wahania i związane $\mathrm{z}$ nimi moralne wątpliwości popychały uczonego $\mathrm{w}$ kierunku swoistego oczyszczenia, intelektualnego katharsis.

Jaka zatem postawa i idea względem historii i przeszłości wynika z tych autorefleksyjnych treści? Ocena nie jest prosta, albowiem Sacharow nie ujmował tych rozważań $w$ kategoriach filozoficznych. Jego relacja z przeszłością ZSRR jest wyłożona w sposób klarowny, ale z dozą osobistego zaangażowania $\mathrm{w}$ opisywane realia. Warto skupić się $\mathrm{w}$ tym miejscu na jednym z najważniejszych świadectw swoistej historiozofii uczonego, czyli dokumencie otwarcia idei, czy też doktryny ${ }^{9}$, Sacharowa. Tekst nazywany jest przez niego broszurą, ale w rzeczywistości mimo relatywnie niewielkiej objętości stanowi swoiste intelektualne credo Sacharowa wkraczającego w 1968 roku, na fali interwencji wojsk Układu Warszawskiego w Czechosłowacji, na ścieżkę otwartego dysydenctwa. Размыиления о прогрессе, мирном сосуществовании и интеллектуальной свободе to jeden z najmocniejszych wykładów przekonań Sacharowa na początku jego opozycyjnej działalności ${ }^{10}$.

Sacharow w maju przekazał przygotowany rękopis do samizdatu, wysłał jeden egzemplarz na ręce Leonida Breżniewa, ale ostatecznie tekst ten trafił do publicznej i międzynarodowej świadomości 6 czerwca w 1968 ro$\mathrm{ku}$, wywieziony poza granice ZSRR i opublikowany częściowo przez tamizdat. 6 czerwca wydrukował go amsterdamski dziennik „Het Parool”, a 22 czerwca - amerykański prestiżowy „The New York Times”. Publikacja dość szybko została rozpropagowana w periodykach niektórych wyższych uczelni w USA, a jej charakter i autorstwo wywołały ożywioną dyskusję ${ }^{11}$.

9 Tak o pisarstwie i idei Sacharowa mówi autor eseju-wstępu do jego dzieł zebranych dysydent i przyjaciel Sacharowa, Jefrem Jankielewicz: Е. Я н к е л е в и ч, Aльтернативы Cахарова, [w:] А. С а х а р о в, Тревога и надежда, т. 1, Москва 2006, s. 15.

${ }^{10} \mathrm{~W}$ języku polskim odnaleźć można jedynie fragment tego tekstu opublikowany w podziemnej oficynie Myśl, a jego tytuł w tłumaczeniu Wiesławy Górskiej brzmi: Rozmyślania o postępie, pokojowym wspótistnieniu i wolności intelektualnej. Patrz: A.D. S a c h a r o w, Rozmyślania, wywiady, propozycje, artykuły, Wydawnictwo „Myśl”, b. m. [Warszawa], b. r. [1990].

11 Świadectwo tej debaty można odnaleźć w informatorze bibliograficznym dotyczącym życia i intelektualnej działalności A. Sacharowa. Patrz: E.H. С а в е л ь е в а, 
Warto pochylić się nad tym tekstem, albowiem obok wielu innych istotnych politycznie i społecznie kwestii, ważnych w ówczesnym ZSRR i świecie, jego autor $w$ pewnych obszarach odnosi się także do dziejów Europy w XX wieku. Z formalno-strukturalnego punktu widzenia esej-memorandum składa się $\mathrm{z}$ dwóch części. Pierwsza poświęcona jest zagadnieniom bezpieczeństwa i stanowi swoistą diagnozą o „stanie świata". Wiele miejsca poświęca Sacharow zagrożeniom, jakim musi w jego odczuciu sprostać ludzkość. Są to wymienione w następującym porządku zjawiska takie jak: zagrożenie wojną jądrową, zagrożenie głodem, zagrożenia ekologiczne (geohigiena), zagrożenie rasizmem, militaryzmem i dyktaturami, zagrożenie dla swobody intelektualnej.

Pierwszym zagrożeniem, które identyfikuje Sacharow, jest zagrożenie wojną termojądrową. To oczywisty kontekst jego zawodowych i intelektualnych zainteresowań. W swym eseju zajmuje jednak stanowisko wychodzące poza dotychczasowe służbowe prerogatywy, które przez lata mogły być rozwijane wyłącznie w charakterze tajnych raportów i analiz. Po omówieniu znanych myślicielowi technicznych możliwości zagłady świata $\mathrm{w}$ wyniku wojny $\mathrm{z}$ użyciem broni masowego rażenia, które wówczas w 1968 roku zgodnie z najlepszą wiedzą Sacharowa były już ogromne, następuje $\mathrm{w}$ tekście sformułowanie pewnych perspektyw odejścia od wojennego napięcia. Pośród gorących punktów na mapie świata, które mogą doprowadzić do głębokiego kryzysu, Sacharow dostrzega między innymi Bliski Wschód wraz z młodym państwem Izrael, Wietnam oraz w jego ocenie najwidoczniej wciąż jeszcze w 1968 roku nierozwiązaną ostatecznie kwestię Niemiec. Postulaty Sacharowa, kierowane do przywódców ZSRR i USA, brzmią ze współczesnej perspektywy dosyć prostodusznie, ale bez wątpienia sięgają sedna problemów związanych z nierównościami społecznymi, politycznymi i ograniczaniem praw człowieka. W Rozmyślaniach sformułowane są następujące zalecenia dla polityki międzynarodowej: narody mają prawo do samostanowienia, oparte o Powszechną Deklarację Praw Człowieka i ONZ, wszystkie próby eksportu rewolucji i kontrrewolucji powinny być nielegalne, a próby ingerencji w struktury polityczne innych państw celem rozszerzenia strefy wpływów powinny zostać wyeliminowane. Tłem do tych rozważań jest część tekstu poświęcona rasizmowi, nacjonalizmowi i reżimom militarystycznym i dyktatorskim. To kolejna istotna z punktu widzenia jego poglądu na historię część broszury Sacharowa, która w szczególności poparta została swoistą interpretacją nieodległej przeszłości ZSRR. Biorąc pod uwagę rok upublicznienia tekstu przez Sacharowa, który ukazał się już ponad 10 lat od sławnego tajnego referatu Nikity Chruszczowa

Андрей Дмитриевич Сахаров. Библиографический справочник II. Литература о жизни и деятельности, кн. 1, Москва 2010, s. 36-40. 
podczas XX zjazdu KPZR, gdzie polityk mierzył się z duchami stalinizmu, można stwierdzić, iż antystalinowski tekst Sacharowa z Rozmyślań... doskonale mieści się $\mathrm{w}$ idei odwilży nawet $\mathrm{z}$ naddatkiem. Warto $\mathrm{w}$ tym miejscu wspomnieć jednak, iż relacje fizyka z przywódcą państwa radzieckiego Nikitą Chruszczowem, choć nie były zbyt częste i bezpośrednie, to jednak już od pewnego czasu, przed publikacją Rozważań... uległy znacznemu pogorszeniu. Sacharow po raz pierwszy miał okazję spotkać Chruszczowa już w roli szefa państwa w 1959 roku podczas narady międzyresortowej na Kremlu. We wspomnieniach fizyka wyraźnie odznaczony został element swoistej przemiany radzieckiego przywódcy, który jeszcze w latach 1953-1955 sprawiał wrażenie polityka trzymającego się nieco w cieniu, aby następnie wyrosnąć od 1956 roku na samodzielnego lidera państwa ${ }^{12}$. Wydarzenia decydujące o zmianie stosunku Chruszczowa do bodaj najwybitniejszego z uczonych pracujących przy badaniach jądrowych miało miejsce 10 czerwca 1961 roku na Kremlu. Na specjalnie zorganizowanym zebraniu członków partii i władz państwa z uczonymi z programu atomowego doszło do otwartego sporu między uczonym a przywódcą ZSRR. Chruszczow zakomunikował na nim swą decyzję o powrocie do systematycznych prób jądrowych w ZSRR. Był to czas, kiedy przekonania Sacharowa na temat ekologicznej i społecznej szkodliwości prób jądrowych, a także wzmacniające się przekonania polityczne nie dawały uczonemu spokoju przy wykonywaniu obowiązków służbowych. Nie znajdując innej formy, ale zdobywając się na odwagę, Sacharow przekazał podczas spotkania za pośrednictwem uczestników spisaną naprędce odręcznie notatkę z informacją-zapytaniem kierowanym do Chruszczowa, której kluczowy fragment, odtworzony z pamięci uczonego we Wspomnieniach, brzmiał mniej więcej tak:

Czy nie sądzicie, że wznowienie doświadczeń zaszkodzi w sposób trudny do naprawienia rozmowom o zakazie prób nuklearnych i całej sprawie rozbrojenia oraz zapewnienia pokoju na świecie? ${ }^{13}$

Uwaga ta spotkała się z bardzo ostrą, publiczną reakcją Chruszczowa. Konflikt między wybitnym akademikiem a premierem ZSRR, który przybierał na sile $\mathrm{w}$ związku $\mathrm{z}$ usztywnianiem się stanowiska Sacharowa względem polityki ZSRR, nie wpłynął jednak istotnie na poglądy uczonego o Chruszczowie. Wspomnienia fizyka, spisywane, jak już wiadomo, w latach 70. XX wieku, nie noszą znamion jakiejś niechęci, a wręcz przeciwnie. Chruszczow w optyce Sacharowa jawi się jako postać, której działania stawiają go w pierwszym rzędzie zasłużonych dla pokoju na świecie:

12 A. С а х а р о в, Воспоминания..., op. cit., s. 466.

${ }^{13}$ Ibidem, s. 476. Tłumaczenie na język polski, którym się tu posługuję, pochodzi z polskiego wydania Wspomnień A. Sacharowa opublikowanych w 1991 roku w przekładzie Danuty Ulickiej (s. 174). 
Но от многих догм Хрущев отошел; именно это, вместе с природным умом и желанием оказаться на высоте положения, - источник его заслуг, которые перевешивают, как я считаю, на весах истории его ошибки и даже преступления ${ }^{14}$ (wyróżnienie moje - B. G.).

Co więcej, ostatnie lata rządów Chruszczowa Sacharow ocenia negatywnie głównie ze względów słabych, niemądrych doradców otaczających polityka.

Strategia analizy politycznej Sacharowa w tym przypadku niebezpiecznie zbliża się do znanego stereotypowego ujęcia "dobry car i źli bojarzy", z tym jednak zastrzeżeniem, iż być może była to także aluzja do ówczesnych rządów Leonida Breżniewa i jego otoczenia, które pchnęło ZSRR z powrotem w objęcia konserwatywnych stalinistów. Uprawdopodobnić tę tezę może stosunek wybitnego fizyka wobec Stalina i epoki stalinizmu, wyrażony na stronach Rozmyślań.... Ostry, krytyczny ton przyjmuje część broszury poświęcona nacjonalizmowi i militaryzmem, która omawia kryzys polityczny i tragedię stalinizmu. Sacharow niewątpliwie korzysta $\mathrm{w}$ tym miejscu ze szlaku przetartego już przez samego Chruszczowa, inicjatora politycznego odprężenia i głównego krytyka stalinizmu. Biorąc pod uwagę jego generalnie pozytywny stosunek do Chruszczowa, fizyk, publikując broszurę, staje się w jakimś sensie jego porte parole, dosadnie i ostro podejmując krytykę politycznych działań Stalina w zdecydowanym i nieczęstym dotąd zestawieniu porównawczym z reżimem Adolfa Hitlera.

Faszyzm w Niemczech przetrwał 12 lat, a stalinizm w ZSRR dwukrotnie dłużej - pisze Sacharow.

Эта специфика сталинизма имела одним из своих следствий то, что самый страшный удар был нанесен против советского народа, его наиболее активных, способных и честных представителей ${ }^{15}$.

Zresztą to właśnie antynarodowa praktyka stalinizmu, jak uważa fizyk, mogła stać się wzorcem dla rozwiniętego nieco później zbrodniczego systemu hitlerowskiego. Sacharow powołuje się tu na autorytet historyka Aleksandra Niekricza, który w 1965 roku opublikował w ZSRR w Wydawnictwie „Nauka" książkę pt. 22 czerwca 1941 roku, tekst, który w sposób absolutnie szczery, nieznany dotąd powszechnie w ZSRR, dekonspirował rzeczywiste relacje stalinowskiego ZSRR i III Rzeszy. Sacharow odwołuje się także do dramatu polityki lat 30. w ZSRR, do represji, tortur i prześladowań wykonywanych na polecenie Stalina przez służby NKWD, do dramatu wsi i brutalnego, nieludzkiego procesu jej rozkułaczania. Stalinowski dogmatyzm, pisze Sacharow, i odklejenie od realnego życia objawił się szczególnie na wsi - w polityce nie dającej się wytrzymać eksploatacji, grabieżczych konfiskat i praktycznie pańszczyźnianego traktowania chłopstwa.

${ }^{14}$ A. С а х а р о в, Воспоминания..., ор. cit., s. 464.

15 A. С а х а р о в, Тревога и надежда, оp. cit., s. 25. 
Krytyka i negatywna ocena dotyczą także radzieckich „obozów śmierci”, jak nazywa Sacharow wszystkie obozy pracy w systemie GUŁAGu, a także polityka narodowościowa realizowana wobec krymskich Tatarów, Niemców z Powołża, Kałmuków i innych środowisk. Niebagatelną rolę w opresyjnej polityce Stalina miała zdaniem Sacharowa także jego ukrainofobia.

Wskazane zbrodnie determinują według myśliciela wszelkie relacje w społeczeństwie poststalinowskim. Na stronach Rozmyślań... Sacharow wyraził również ubolewanie, że nie udało się doprowadzić do pośmiertnego usunięcia Józefa Stalina z KPZR, a także rehabilitacji ofiar stalinizmu, co w jego ocenie mogło mieć miejsce w 1964 roku, przy okazji zmiany władzy na Kremlu16.

Druga część broszury to wykład o nadziejach dla ludzkości, które autor dostrzega, mimo śmiertelnego zwarcia dwóch wrogich wobec siebie światów. W pewnym uproszczeniu chodzi rzecz jasna o dwóch politycznych aktorów zimnej wojny, świat kapitalistyczny i socjalistyczny, USA i ZSRR. Rozwiązaniem problemu napięć w dwubiegunowym świecie dostrzega Sacharow w rozumnej konwergencji systemu kapitalistycznego z socjalistycznym:

Капиталистический мир не мог не породить социалистического; но социалистический мир не должен разрушать методом вооруженного насилия породившую его почву - это было бы самоубийством человечества в сложившихся конкретных условиях ${ }^{17}$.

W dalszej części tekstu Andriej Sacharow w kliku punktach podaje, najszybsze jego zdaniem, drogi rozwiązania problemów zimnowojennego świata. Są to zmiany w strukturze własności w krajach socjalistycznych i towarzyszące im jednocześnie socjalne reformy w państwach kapitalistycznych. Nadzieja Sacharowa oparta jest na dobrej wierze wobec intencji głównych graczy na międzynarodowej scenie politycznej. Ci jednak powinni w jego odczuciu odrzucić swoje partykularne interesy dla dobra ogółu ${ }^{18}$. Te dość naiwnie i idealistycznie brzmiące tezy są być może owocem

16 Stąd późniejsze listy i starania o potępienie Stalina, w których wziął udział Andriej Sacharow i o których była mowa wyżej, kierowane do Leonida Breżniewa.

17 A. С а х а р о в, Тревога и надежда, ор. cit., s. 42.

18 Andriej Sacharow również w administracji USA poszukiwał ludzi chętnych do dialogu i dążących do niekonfrontacyjnych rozstrzygnięć w negocjacjach międzypaństwowych. Pewne nadzieje $w$ tej kwestii dawała początkowo 35 prezydentura w USA, sprawowana przez demokratę Johna Kennedy'ego, ale została zmarnowana przez radzieckiego przywódcę. Myśliciel wskazuje tu na niewłaściwą postawę Nikity Chruszczowa, który w jednym z wystąpień publicznych na Kremlu miał ostro zareagować na prośbę amerykańskiego prezydenta o zachowanie pewnego rodzaju kredytu życzliwości i zaufania ze strony przywódcy ZSRR. Oczekiwanie to zostało wyrażone przez Johna Kennedy'ego 
obserwacji przemian, jakie w latach 60. przechodził ZSRR, ale także przemian zachodzących $\mathrm{w}$ duchowości samego fizyka. Odwilż inspirowana przez Nikitę Chruszczowa, tego, który jeszcze do niedawna u boku Stalina milcząco współrealizował najbardziej zbrodnicze projekty systemu, wielu wydawała się zapewne absolutnie nierealna. A jednak doszło do przełamania i swoistego, choć niezbyt głębokiego, osądu stalinizmu. Uważny obserwator tego procesu, a w pewnym sensie także jego beneficjent, jakim był Andriej Sacharow, publikujący swe postulaty w 1968 roku, miał prawo do nadmiernego patosu i idealizmu w formułowanych sądach. Analizując biografię uczonego, należy także podejrzewać, że na takim postrzeganiu rzeczywistości zaważyły również jego cechy osobowościowe.

Rozmyślania o postępie, pokojowym wspótistnieniu $i$ wolności intelektualnej kończy fragment poświęcony pożądanej przez autora projekcji przyszłości, włączywszy w to zalecenia lub plany umożliwiające rozstrzygnięcie najbardziej palących kwestii. Sacharow pisze tu o współpracy międzynarodowej i dialogu opartym na nauce i wiedzy, pisze o walce z głodem, sugeruje opracowanie w ZSRR nowego prawa informacyjnego, dającego większą swobodę wypowiedzi, postuluje kasację praw, które są antykonstytucyjne, i amnestię więźniów politycznych ${ }^{19}$. Być może najważniejszy dezyderat uczonego zawarty $\mathrm{w}$ tym tekście odwołuje się do zainicjowania zdecydowanego i nieodwołalnego procesu destalinizacji sowieckiego systemu politycznego. Jest to odwołanie niezależnego umysłu do piekielnej nieodległej historii, która obciąża narody funkcjonujące $\mathrm{w}$ tym systemie. Zrzucenie jarzma stalinizmu jest kwestią obowiązkową i warunkiem koniecznym do tego, aby nadzieje uczonego na dialog międzynarodowy w dobie zimnej wojny mogły się ziścić. Paradoksem biografii Sacharowa jest to, iż nie uczestniczył czynnie jako żołnierz w wielkiej wojnie ojczyźnianej, zwycięskiej kampanii wielkiego Stalina, ale już $\mathrm{w}$ czasie powojennym był jednym $\mathrm{z}$ filarów kontekstu nowej, zimnej wojny, jako intelektualny wysoki oficer sowieckiego programu zbrojeniowego. Lekcja płynąca z mroków stalinizmu lat 30. XX wieku ma dla fizyka charakter ponadnarodowy, zwraca on uwage na możliwość odrodzenia się bądź kontynuacji $\mathrm{w}$ niektórych regionach świata tego rodzaju twardej dyktatury.

w kontekście politycznych wewnętrznych ograniczeń i braku doświadczenia jego nowej administracji, wprowadzonej do Białego Domu na początku 1961 roku. Taka zdecydowana i grubiańska w opinii Sacharowa wypowiedź Nikity Chruszczowa miała mieć miejsce 10 lipca 1961 roku na spotkaniu ze specjalistami ds. atomistyki w Moskwie. Patrz przypis A. Sacharowa w broszurze Rozmyślania...: A. С а х а р о в, Тревога и надежda, op. cit., s. 43.

19 Sacharow osobiście najintensywniej zaangażowany był $\mathrm{w}$ proces uwolnienia dwóch literatów - Julija Daniela i Andrieja Siniawskiego, co stało się dopiero w 1970 i 1971 roku. 
Broszura Andrieja Sacharowa opublikowana w 1968 roku w pewnym zakresie koresponduje z pokojową i pozarządową inicjatywą o nazwie Pugwash z 1955 roku, firmowaną przez zachodnich myślicieli i uczonych fizyków. Oświadczenie wygłoszone przez brytyjskiego filozofa Bertranda Russela w dziesiątą rocznicę tragicznych zrzutów ładunków atomowych na japońskie miasta Hiroszimę i Nagasaki ${ }^{20}$ było równocześnie jednym z ostatnich publicznych aktów działalności genialnego fizyka Alberta Einsteina i nadało tej idei światowego prestiżu. Inicjatywa Pugwash od 1957 roku podjęła działanie na rzecz pokoju na świecie poprzez ograniczenie prac związanych $\mathrm{z}$ rozwojem bomby atomowej i przeciwdziałanie konfliktowi zbrojnemu $\mathrm{z}$ użyciem tej śmiercionośnej siły.

Tak zwany Manifest Einsteina i Russela, sygnowany między innymi także przez wybitnych teoretyków atomistyki polskiego pochodzenia - Józefa Rotblata i Leopolda Infelda, być może nie był znany Sacharowowi w 1968 roku, wiadomo jednak, że od 1975 roku, kiedy radziecki uczony został uhonorowany Pokojową Nagrodą Nobla, jego intelektualne związki $\mathrm{z}$ tą organizacją nabrały pewnej dynamiki ${ }^{21}$. Różnica między inicjatywą z Pugwash a późniejszym wystąpieniem Sacharowa jest jednak zasadnicza. Radziecki fizyk z wielką atencją odniósł swoje rozważania na temat przyszłości stanu świata do nieodległej historii swojego państwa. Pogłębiona analiza historyczna jest wartością dodaną i pełniej opisuje międzynarodową rzeczywistość. Jego broszura oprócz walorów postulatywnych ma także wartość wspomagającą konstrukcję nowego pokojowego świata. Opiera się ona na wciąż jeszcze trudnej w ZSRR w 1968 roku krytycznej analizie i interpretacji epoki stalinizmu, zwłaszcza fatalnych społecznie i politycznie dla sowieckiego państwa lat 30. XX wieku.

W optyce Andrieja Sacharowa dyktatura stalinowska z jej okrucieństwami jest bolesną nauką nie tylko dla ZSRR, ale i dla całego świata. Wyciągnięcie z niej właściwych wniosków może dać nadzieję na bezpieczny i zrównoważony rozwój nawet w obliczu zimnowojennego napięcia. Stalinizm stanowi w poetyce tekstu Rozmyślań o postępie, pokojowym wspótistnieniu $i$ wolności intelektualnej trudną lekcję, której rzetelne odrobienie przez obie strony zimnowojennego konfliktu może określić warunki postępu i drogi ku pokojowi. Odczytywane dziś antywojenne, antytotalitarne i wolnościowe idee Andrieja Sacharowa sprzed ponad czterdziestu lat w wielu punktach porażają swą ponadczasowością. Współczesne realia wskazują na to, iż obecne relacje międzynarodowe, a także istnienie specyficznej Patrio-

20 Oświadczenie zostało wygłoszone 9 lipca 1955 roku w Londynie, ale konferencje uczonych odbywały się w Pugwash w kanadyjskiej prowincji Nowa Szkocja od 1957 roku.

${ }^{21}$ Sacharow, nie opuszczając ZSRR, w 1975 i 1982 roku kierował do uczestników konferencji Pugwash listy. 
tyczno-konserwatywnej, jak niektórzy zauważają, neoimperialnej linii ideowej i atmosfery swoistego rewanżyzmu we współczesnej Rosji, chyba jak nigdy dotąd świadomego dziedzica ZSRR w jego najbardziej ekspansjonistycznych przejawach, skłaniają dziś do powtórnej lektury i rzetelnej analizy odwilżowej myśli Sacharowa.

\section{Bibliografia}

S a c h a r o w A.D., Rozmyślania, wywiady, propozycje, artykuty, Wydawnictwo "Myśl”, b. m. [Warszawa], b. r. [1990].

Письмо 25-ти деятелей советской науки, литературы и искусства Л.И. Брежневу против реабилитации И.В. Сталина, [w:] Электронная библиотека и архив Социальная история отечественной науки; http://www.ihst.ru/projects/sohist/

С а в е л ь е в а Е.Н., Андрей Дмитриевич Сахаров. Библиографический справочник II. Литература о жизни и деятельности, кн. 1, Москва 2010.

С а х а р о в А., Воспоминания, т. 1, Москва 2006.

С а х а р о в А., Тревога и надежда, т. 1, Москва 2006.

Я н к е л е в и ч Е., Альтернативы Сахарова, [w:] А. С а х а р о в, Тревога и надежда, т. 1, Москва 2006, s. 15. 